\title{
PENGENALAN POLA PERILAKU SEORANG MANUSIA DALAM PERMAINAN SUTEN MENGGUNAKAN METODE JARINGAN SARAF TIRUAN PROPAGASI BALIK
}

\author{
M. Irwan Ukkas ${ }^{1)}$, Awang Harsa Kridalaksana ${ }^{2)}$, Tjeng Wawan Cenggoro ${ }^{3)}$ \\ ${ }^{2,3}$ Teknik Informatika, STMIK Widya Cipta Dharma Samarinda \\ ${ }^{1}$ Sistem Informasi, STMIK Widya Cipta Dharma Samarinda \\ 1,2,3 Jl. M. Yamin No. 25, Samarinda, 75123 \\ E-mail :, Irwan212@yahoo.com ${ }^{1)}$, awangkid@gmail.com ${ }^{2)}$,wawancenggoro@gmail.com ${ }^{3)}$
}

\begin{abstract}
ABSTRAK
Jaringan saraf tiruan merupakan suatu paradigma pemrosesan informasi yang mengambil permodelan dari cara kerja jaringan saraf biologi dalam memroses informasi sehingga memiliki kemampuan yang mirip dengan otak manusia. Jaringan saraf tiruan mampu menyelesaikan berbagai masalah yang mengandung ketidak pastian di dalamnya, yang biasanya hanya bisa diselesaikan oleh manusia. Permasalahan tersebut antara lain adalah pengenalan pola.

Tujuan dari penelitian ini adalah untuk mengetahui efektivitas dari metode jaringan saraf tiruan propagasi balik untuk mengenali pola perilaku manusia dalam permainan suten. Hasil dari penelitian ini adalah berupa aplikasi yang menggunakan jaringan saraf tiruan untuk mengenali pola perilaku manusia dalam permainan suten dan efektivitas dari metode jaringan saraf tiruan propagasi balik untuk mengenali pola perilaku manusia dalam permainan suten.
\end{abstract}

Kata Kunci: Pengenalan Pola, Pola Perilaku Manusia, Permainan Suten, Jaringan Saraf Tiruan, Propagasi Balik.

\begin{tabular}{ll}
\hline 1. PENDAHULUAN & \multicolumn{2}{c}{ Permainan suten dapat digunakan untuk membatasi } \\
Dalam ilmu komputer, khususnya di bidang & pola perilaku manusia. Permainan suten memberikan \\
kecerdasan buatan, dikenal sebuah metode yang disebut & pola yang terbatas namun dapat mencerminkan \\
dengan jaringan saraf tiruan. Jaringan saraf tiruan & kecenderungan dari perilaku manusia yang \\
merupakan suatu paradigma pemrosesan informasi yang & memainkannya. Pada penelitian ini, jaringan saraf tiruan \\
mengambil permodelan dari cara kerja jaringan saraf & akan mengenali pola permainan suten yang dikeluarkan \\
biologi dalam memroses informasi. Latar belakang & oleh subjek penelitian.
\end{tabular}
perkembangan jaringan saraf tiruan didasari oleh keinginan agar komputer mampu menirukan kemampuan manusia dalam memroses informasi.

Jaringan saraf tiruan telah terbukti mampu untuk menyelesaikan berbagai masalah yang mengandung ketidak pastian di dalamnya, yang biasanya hanya bisa diselesaikan oleh manusia. Beberapa masalah tersebut antara lain adalah peramalan, pengenalan wajah, pengenalan tulisan tangan, dan pengenalan suara. Masalah-masalah ini tidak dapat diselesaikan oleh metode-metode perhitungan pada umumnya. Dapat dikatakan bahwa jaringan saraf tiruan merupakan salah satu paradigma pemrosesan informasi yang paling mendekati kemampuan pemrosesan informasi manusia.

Melihat kemiripan paradigma pemrosesan data antara jaringan saraf tiruan dan otak manusia tersebut, timbul suatu pertanyaan yaitu sejauh mana jaringan saraf tiruan mampu mengenali pola perilaku yang dihasilkan dari otak manusia. Namun, diperlukan suatu media yang baik untuk membatasi pola tersebut sehingga menjadi pola yang dapat dibaca dengan mudah oleh komputer.

\section{RUANG LINGKUP PENELITIAN}

Masalah yang akan dibahas dalam penelitian ini adalah efektivitas dari metode jaringan saraf tiruan propagasi balik dalam mengenali pola perilaku manusia dalam permainan suten.

Permasalahan yang telah dipaparkan akan difokuskan dalam batasan-batasan berikut:

1. Pola perilaku manusia dalam permainan suten yang dikenali oleh jaringan saraf tiruan hanya sebatas pada:

1) Input berupa pilihan suten yang digunakan baik oleh subjek manusia yang diteliti maupun lawan dalam dua sesi permainan berturut-turut. Pilihan suten yang digunakan lawan main selama proses pengenalan merupakan pilihan secara acak yang dibangkitkan oleh komputer.

2) Output berupa pilihan suten yang digunakan oleh subjek manusia yang diteliti pada sesi permainan ketiga tepat setelah dua sesi permainan yang dikenali sebelumnya. 
2. Efektivitas yang diukur berupa selisih antara persentase kemenangan komputer yang menggunakan jaringan saraf tiruan yang telah mengenali pola perilaku subjek penelitian dan persentase kemenangan komputer yang tidak menggunakan jaringan saraf tiruan.

3. Subjek penelitian adalah manusia yang dikenali pola perilakunya oleh jaringan saraf tiruan.

4. Jenis variasi permainan suten yang digunakan pada penelitian ini adalah suten yang menggunakan bentuk tangan gunting, batu, dan kertas.

5. Jumlah pemain suten hanya berjumlah dua orang, yaitu komputer dan subjek penelitian.

6. Kondisi emosi subjek penelitian yang akan diteliti hanya terbatas pada kondisi emosi yang tenang. Kondisi yang tenang ini didefinisikan sebagai keadaan emosi setelah subjek melakukan meditasi singkat, dengan objek meditasi berupa pernafasan, selama kurang lebih satu menit.

7. Jenis jaringan saraf tiruan yang digunakan pada penelitian ini adalah sebagai berikut:

1) Jenis arsitektur jaringan saraf tiruan adalah jaringan saraf tiruan umpan maju dengan layar banyak (multi-layer feed-forward neural network).

2) Pelatihan jaringan saraf tiruan yang digunakan adalah propagasi balik (back propagation) dengan variasi menggunakan momentum.

8. Rancangan arsitektur jaringan saraf tiruan yang digunakan dalam penelitian ini adalah sebagai berikut:

1) Jumlah neuron yang digunakan pada layar input adalah empat neuron.

2) Jumlah neuron yang digunakan pada layar tersembunyi ditentukan secara dinamis

3) Jumlah neuron yang digunakan pada layar output adalah satu neuron.

9. Parameter jaringan saraf tiruan yang digunakan pada penelitian ini adalah sebagai berikut:

1) Batas toleransi nilai kesalahan menggunakan fungsi mean square error dengan nilai 0,0001.

2) Fungsi aktivasi yang digunakan untuk koneksi antara neuron pada layar input dan layar tersembunyi adalah fungsi sigmoid bipolar.

3) Fungsi aktivasi yang digunakan untuk koneksi antara neuron pada layar tersembunyi dan layar output adalah fungsi linear.

4) Jumlah epoch maksimum diatur secara dinamis pada aplikasi.

5) Parameter momentum diatur secara dinamis pada aplikasi.

6) Laju pemahaman (learning rate) diatur secara dinamis pada aplikasi.

\section{BAHAN DAN METODE}

Penyajian teori dan metode yang digunakan untuk mengembangkan sistem

\subsection{Jaringan Saraf Tiruan (Artificial Neural Network)}

Menurut Siang (2005), jaringan saraf tiruan adalah sistem pemroses informasi yang memiliki karakteristik mirip jaringan saraf biologi. Jaringan saraf tiruan dibentuk sebagai generalisasi model matematika dari jaringan saraf biologi, dengan asumsi:

1. Pemrosesan informasi terjadi pada banyak elemen sederhana (neuron).

2. Sinyal dikirimkan diantara neuron-neuron melalui penghubung-penghubung.

3. Penghubung antar neuron memiliki bobot yang akan memperkuat atau memperlemah sinyal.

4. Untuk menentukan output, setiap neuron menggunakan fungsi aktivasi yang dikenakan pada jumlahan input yang diterima. Besarnya output ini selanjutnya dibandingkan dengan batas ambang.

\subsection{Algoritma Backpropagation}

Algoritma pelatihan propagasi balik (backpropagation) adalah pengembangan dari algoritma pelatihan perceptron yang menggunakan arsitektur jaringan layar banyak. Algoritma pelatihan propagasi balik mampu mengatasi keterbatasan pengenalan pola pada algoritma-algoritma sebelumnya

Fungsi aktivasi yang dipakai dalam propagasi balik harus memenuhi beberapa syarat, yaitu kontinu, mudah didiferensialkan dan merupakan fungsi yang tidak turun. Fungsi yang memenuhi ketiga syarat tersebut dan populer digunakan pada propagasi balik adalah sigmoid biner dan sigmoid bipolar.

Pelatihan dengan algoritma propagasi balik meliputi tiga fase:

1. Fase 1: propagasi maju

Selama propagasi maju, sinyal masukan dipropagasikan ke layar tersembunyi menggunakan fungsi aktivasi yang sudah ditentukan. Keluaran dari setiap unit layar tersembunyi tersebut selanjutnya dipropagasikan maju lagi ke layar tersembunyi berikutnya. Berikut seterusnya hingga menghasilkan output dari layar output. Berikutnya output dibandingkan dengan nilai target. Jika selisihnya lebih kecil dari batas toleransi yang ditentukan, maka proses iterasi berhenti. Jika tidak, maka lanjutkan ke fase berikutnya.

2. Fase 2: propagasi mundur

Berdasarkan selisih output dan target, dihitung faktor kesalahan yang dipakai untuk mendistribusikan kesalahan di layar output ke semua layar tersembunyi yang berhubungan. Faktor kesalahan tersebut juga dipakai untuk mengubah bobot garis yang berhubungan. Dengan cara yang sama, dihitung faktor kesalahan pada layar tersembunyi kemudian kesalahan didistribusikan ke layar tersembunyi sebelumnya. Demikian seterusnya hingga faktor kesalahan pada layar tersembunyi yang berhubungan dengan layar input dihitung.

3. Fase 3: perubahan bobot

Setelah semua faktor kesalahan dihitung, bobot semua garis dubah bersamaan. Perubahan bobot didasarkan atas faktor kesalahan neuron di layar berikutnya.

Ketiga fase tersebut diulang-ulang terus hingga kondisi penghentian dipenuhi. Umumnya kondisi penghentian yang sering dipakai adalah jumlah epoch atau batas toleransi kesalahan. 


\subsection{Model Unified Software Development Process (USDP)}

Menurut Nugroho (2010), USDP merupakan metode pengembangan/rekayasa perangkat lunak yang berbasiskan komponen, yang berarti sistem perangkat lunak yang kelak dihasilkan akan terdiri atas komponenkomponen perangkat lunak yang saling terhubung melalui antarmuka yang terdefinisi dengan baik. USDP menggunakan Unified Modelling Language (UML) sebagai kakas bantu utama analisis dan perancangan sistem /perangkat lunak. USDP, seperti yang dikemukakan para penciptanya (Graddy Booch, Ivan Jacobson, serta DR. James Rumbaugh) memiliki karakteristik use-case driven sehingga use case diagram merupakan kendali dalam seluruh tahapan pengembangan sistem/perangkat lunak, mulai perencanaan, analisis, perancangan hingga implementasi. Karakteristik lainnya adalah architecture centric dan iterative and incremental. Architecture centric berarti pengembangan berpusat pada aspek-aspek statis dan dinamis dari perangkat lunak. Iterative and incremental berarti pengembangan dilakukan dalam beberapa komponen kecil yang kemudian diintegrasikan ke dalam satu perangkat lunak yang utuh.

\section{RANCANGAN SISTEM/APLIKASI}

Berikut adalah rancangan sistem dan perancangan basisdata

\subsection{Diagram Use Case}

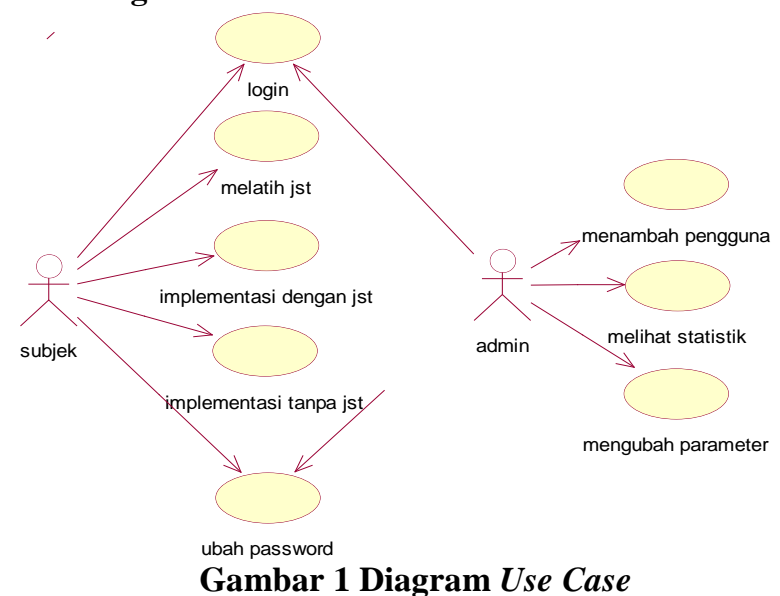

Subjek penelitian sebagai aktor memiliki lima use case, yaitu login, melatih jst, implementasi dengan jst, implementasi tanpa jst, dan ubah password. Admin sebagai aktor memiliki lima use case, yaitu login, menambah pengguna, melihat statistik, mengubah parameter, dan ubah password.

\subsection{Arsitektur Jaringan Saraf Tiruan}

Layar input berisi empat neuron untuk mengambil empat input pola pilihan suten dari subjek penelitian dan komputer untuk dua sesi permainan. Layar output berisi satu neuron sebagai output berupa pola suten apa yang dipilih oleh subjek penelitian setelah dua sesi permainan. Batas toleransi kesalahan berupa batas nilai MSE yang digunakan adalah 0,0001. Jumlah epoch maksimum yang digunakan adalah 100 epoch. Jumlah layar tersembunyi yang digunakan sebanyak satu layar. Jumlah neuron pada layar tersembunyi, nilai laju pemahaman, dan nilai parameter momentum ditentukan berdasarkan hasil percobaan berikut:

Set data pelatihan:

1. Input Pertama $=0,3$

2. Input Kedua $=0,6$

3. Input Ketiga $=0,9$

4. Input Keempat $=0,3$

5. Output $=0,75$

Tabel 1 Percobaan Parameter Jumlah Neuron Layar Tersembunyi

\begin{tabular}{|c|c|c|c|c|c|c|c|c|c|}
\hline $\begin{array}{c}\text { Jumlah } \\
\text { Neuron Layar } \\
\text { Tersembunyi } \\
\end{array}$ & \multicolumn{3}{|c|}{5} & \multicolumn{3}{|c|}{7} & \multicolumn{3}{|c|}{9} \\
\hline $\begin{array}{c}\text { Laju } \\
\text { Pemahaman }\end{array}$ & \multicolumn{3}{|c|}{0.01} & \multicolumn{3}{|c|}{0.01} & \multicolumn{3}{|c|}{0.01} \\
\hline $\begin{array}{c}\text { Nilai } \\
\text { Parameter } \\
\text { Momentum }\end{array}$ & \multicolumn{3}{|c|}{0.9} & \multicolumn{3}{|c|}{0.9} & \multicolumn{3}{|c|}{0.9} \\
\hline Percobaan ke- & 1 & 2 & 3 & 1 & 2 & 3 & 1 & 2 & 3 \\
\hline $\begin{array}{c}\text { Jumlah Epoch } \\
\text { yang } \\
\text { Ditempuh }\end{array}$ & 95 & 58 & 31 & 35 & 31 & 30 & 45 & 45 & 100 \\
\hline $\begin{array}{c}\text { Hasil } \\
\text { Pelatihan }\end{array}$ & $\mathrm{v}$ & $\mathrm{v}$ & $\mathrm{V}$ & $\mathrm{V}$ & $\mathrm{v}$ & $\mathrm{v}$ & $\mathrm{v}$ & $\mathrm{V}$ & $\mathrm{x}$ \\
\hline $\begin{array}{c}\text { Rata-rata } \\
\text { Jumlah Epoch }\end{array}$ & \multicolumn{3}{|c|}{61,333} & \multicolumn{3}{|c|}{32} & \multicolumn{3}{|c|}{63,333} \\
\hline
\end{tabular}

Tabel 2 Percobaan Parameter Laju Pemahaman

\begin{tabular}{|c|c|c|c|c|c|c|c|c|c|}
\hline $\begin{array}{c}\text { Jumlah } \\
\text { Neuron Layar } \\
\text { Tersembunyi }\end{array}$ & \multicolumn{3}{|c|}{7} & \multicolumn{3}{|c|}{7} & \multicolumn{3}{|c|}{7} \\
\hline $\begin{array}{c}\text { Laju } \\
\text { Pemahaman }\end{array}$ & \multicolumn{3}{|c|}{0.01} & \multicolumn{3}{|c|}{0.001} & \multicolumn{3}{|c|}{0.1} \\
\hline $\begin{array}{c}\text { Nilai } \\
\text { Parameter } \\
\text { Momentum }\end{array}$ & \multicolumn{3}{|c|}{0.9} & \multicolumn{3}{|c|}{0.9} & \multicolumn{3}{|c|}{0.9} \\
\hline Percobaan ke- & 1 & 2 & 3 & 1 & 2 & 3 & 1 & 2 & 3 \\
\hline $\begin{array}{c}\text { Jumlah Epoch } \\
\text { yang } \\
\text { Ditempuh }\end{array}$ & 35 & 31 & 30 & 100 & 100 & 100 & 100 & 9 & 100 \\
\hline $\begin{array}{c}\text { Hasil } \\
\text { Pelatihan }\end{array}$ & $\mathrm{v}$ & $\mathrm{V}$ & $\mathrm{V}$ & $\mathrm{x}$ & $\mathrm{x}$ & $\mathrm{x}$ & $\mathrm{x}$ & $\mathrm{v}$ & $\mathrm{x}$ \\
\hline $\begin{array}{c}\text { Rata-rata } \\
\text { Jumlah Epoch }\end{array}$ & \multicolumn{3}{|c|}{32} & \multicolumn{3}{|c|}{100} & \multicolumn{3}{|c|}{69,667} \\
\hline
\end{tabular}

Tabel 3 Percobaan Parameter Momentum

\begin{tabular}{|c|c|c|c|c|c|c|c|c|c|}
\hline $\begin{array}{c}\text { Jumlah } \\
\text { Neuron Layar } \\
\text { Tersembunyi }\end{array}$ & \multicolumn{3}{|c|}{7} & \multicolumn{3}{|c|}{7} & \multicolumn{3}{|c|}{7} \\
\hline $\begin{array}{c}\text { Laju } \\
\text { Pemahaman }\end{array}$ & \multicolumn{3}{|c|}{0.01} & \multicolumn{3}{|c|}{0.01} & \multicolumn{3}{|c|}{0.01} \\
\hline $\begin{array}{c}\text { Nilai } \\
\text { Parameter } \\
\text { Momentum } \\
\end{array}$ & \multicolumn{3}{|c|}{0.9} & \multicolumn{3}{|c|}{0.8} & \multicolumn{3}{|c|}{0.7} \\
\hline Percobaan ke- & 1 & 2 & 3 & 1 & 2 & 3 & 1 & 2 & 3 \\
\hline $\begin{array}{c}\text { Jumlah Epoch } \\
\text { yang } \\
\text { Ditempuh }\end{array}$ & 35 & 31 & 30 & 100 & 100 & 100 & 100 & 100 & 100 \\
\hline $\begin{array}{c}\text { Hasil } \\
\text { Pelatihan }\end{array}$ & $\mathrm{v}$ & $\mathrm{v}$ & $\mathrm{v}$ & $\mathrm{x}$ & $\mathrm{x}$ & $\mathrm{x}$ & $\mathrm{x}$ & $\mathrm{x}$ & $\mathrm{X}$ \\
\hline $\begin{array}{c}\text { Rata-rata } \\
\text { Jumlah } \text { Epoch }\end{array}$ & \multicolumn{3}{|c|}{32} & \multicolumn{3}{|c|}{100} & \multicolumn{3}{|c|}{100} \\
\hline
\end{tabular}

Keterangan:

1. $\mathrm{v}=$ Pelatihan berhasil

2. $\mathrm{x}=$ Pelatihan gagal 
Berdasarkan hasil percobaan yang ditampilkan pada tabel 1, tabel 2, dan tabel 3, dapat disimpulkan bahwa jumlah neuron layar tersembunyi $=7$; laju pemahaman $=$ 0,01 ; dan nilai parameter momentum $=0,9$ memberikan hasil yang paling optimal.

\subsection{Struktur Basis Data}

Nama Tabel: tb_login

Primary Key: username

Keterangan: tabel 4 menunjukkan struktur tabel basis data yang digunakan untuk menyimpan data pengguna

Tabel 4 Struktur Tabel Login

\begin{tabular}{|l|l|l|l|}
\hline $\begin{array}{l}\text { Nama } \\
\text { Field }\end{array}$ & $\begin{array}{l}\text { Tipe } \\
\text { Data }\end{array}$ & Lebar & Deskripsi \\
\hline username & Varchar & 30 & $\begin{array}{l}\text { Nama yang } \\
\text { digunakan untuk } \\
\text { login, Primary Key }\end{array}$ \\
\hline password & Varchar & 50 & Password login \\
\hline
\end{tabular}

Nama Tabel: tb_parameter

Primary Key: -

Keterangan: tabel 5 menunjukkan struktur tabel basis data yang digunakan untuk menyimpan parameter jaringan saraf tiruan

Tabel 5 Struktur Tabel Parameter

\begin{tabular}{|c|c|c|c|}
\hline Nama Field & $\begin{array}{c}\text { Tipe } \\
\text { Data }\end{array}$ & Lebar & Deskripsi \\
\hline hidden_layer & int & 11 & $\begin{array}{c}\text { Menyimpan } \\
\text { parameter jumlah } \\
\text { layar tersembunyi }\end{array}$ \\
\hline learning_rate & float & - & $\begin{array}{c}\text { Menyimpan } \\
\text { parameter laju } \\
\text { pemahaman }\end{array}$ \\
\hline epoch & int & 11 & $\begin{array}{c}\text { Menyimpan } \\
\text { parameter jumlah } \\
\text { epoch maksimum }\end{array}$ \\
\hline momentum & float & - & $\begin{array}{c}\text { Menyimpan } \\
\text { parameter variabel } \\
\text { momentum }\end{array}$ \\
\hline
\end{tabular}

Nama Tabel: tb_iw

Primary Key: username, i, j

Keterangan: tabel 6 menunjukkan struktur tabel basis data yang digunakan untuk menyimpan bobot dari layar input

Tabel 6 Struktur Tabel Bobot Layar Input

\begin{tabular}{|c|c|c|c|}
\hline $\begin{array}{c}\text { Nama } \\
\text { Field }\end{array}$ & $\begin{array}{c}\text { Tipe } \\
\text { Data }\end{array}$ & Lebar & Deskripsi \\
\hline username & varchar & 30 & $\begin{array}{c}\text { Menyimpan username } \\
\text { dari pengguna yang } \\
\text { dikenali oleh jaringan } \\
\text { saraf tiruan }\end{array}$ \\
\hline $\mathrm{i}$ & int & 4 & $\begin{array}{c}\text { Menyimpan nomor } \\
\text { simpul layar input }\end{array}$ \\
\hline $\mathrm{j}$ & int & 4 & $\begin{array}{c}\text { Menyimpan nomor } \\
\text { simpul layar } \\
\text { tersembunyi tujuan }\end{array}$ \\
\hline nilai & float & - & Menyimpan bobot \\
\hline
\end{tabular}

Nama Tabel: tb_lw

Primary Key: username, from_layer, to_layer, i, j Keterangan: tabel 7 menunjukkan struktur tabel basis data yang digunakan untuk menyimpan bobot dari layar tersembunyi

Tabel 7 Struktur Tabel Bobot Layar Tersembunyi

\begin{tabular}{|c|c|c|c|}
\hline $\begin{array}{c}\text { Nama } \\
\text { Field }\end{array}$ & $\begin{array}{c}\text { Tipe } \\
\text { Data }\end{array}$ & Lebar & Deskripsi \\
\hline username & varchar & 30 & $\begin{array}{c}\text { Menyimpan } \\
\text { username dari } \\
\text { pengguna yang } \\
\text { dikenali oleh } \\
\text { jaringan saraf tiruan }\end{array}$ \\
\hline from_layer & int & 4 & $\begin{array}{c}\text { Menyimpan nomor } \\
\text { layar asal }\end{array}$ \\
\hline to_layer & int & 4 & $\begin{array}{c}\text { Menyimpan nomor } \\
\text { layar tujuan }\end{array}$ \\
\hline i & int & 4 & $\begin{array}{c}\text { Menyimpan nomor } \\
\text { simpul layar } \\
\text { tersembunyi }\end{array}$ \\
\hline j & int & 4 & $\begin{array}{c}\text { Menyimpan nomor } \\
\text { simpul layar tujuan }\end{array}$ \\
\hline nilai & float & - & Menyimpan bobot \\
\hline
\end{tabular}

Nama Tabel: tb_bias

Primary Key: username, layer, to_neuron

Keterangan: tabel 8 menunjukkan struktur tabel basis data yang digunakan untuk menyimpan bobot bias jaringan saraf tiruan

Tabel 8 Struktur Tabel Bobot Bias

\begin{tabular}{|c|c|c|c|}
\hline $\begin{array}{c}\text { Nama } \\
\text { Field }\end{array}$ & $\begin{array}{c}\text { Tipe } \\
\text { Data }\end{array}$ & Lebar & Deskripsi \\
\hline username & varchar & 30 & $\begin{array}{c}\text { Menyimpan } \\
\text { username dari } \\
\text { pengguna yang } \\
\text { dikenali oleh jaringan } \\
\text { saraf tiruan }\end{array}$ \\
\hline layer & int & 4 & $\begin{array}{c}\text { Menyimpan nomor } \\
\text { layar asal }\end{array}$ \\
\hline to_neuron & int & 4 & $\begin{array}{c}\text { Menyimpan nomor } \\
\text { simpul layar tujuan }\end{array}$ \\
\hline nilai & float & - & \begin{tabular}{c} 
Menyimpan bobot \\
\hline
\end{tabular} \\
\hline
\end{tabular}

Nama Tabel: tb_statistik

Primary Key: username

Keterangan: tabel 9 menunjukkan struktur tabel basis data yang digunakan untuk menyimpan statistik kemenangan 
Tabel 9 Struktur Tabel Statistik

\begin{tabular}{|c|c|c|c|}
\hline Nama Field & $\begin{array}{l}\text { Tipe } \\
\text { Data }\end{array}$ & Lebar & Deskripsi \\
\hline username & varchar & 30 & $\begin{array}{c}\text { Menyimpan } \\
\text { username dari } \\
\text { pengguna yang } \\
\text { dikenali oleh } \\
\text { jaringan saraf } \\
\text { tiruan }\end{array}$ \\
\hline menang_nojst & int & 2 & $\begin{array}{c}\text { Menyimpan } \\
\text { jumlah menang } \\
\text { komputer yang } \\
\text { tidak } \\
\text { menggunakan } \\
\text { jaringan saraf } \\
\text { tiruan terhadap } \\
\text { pengguna dengan } \\
\text { username sesuai } \\
\text { dengan field } \\
\text { username }\end{array}$ \\
\hline seri_nojst & int & 2 & $\begin{array}{c}\text { Menyimpan } \\
\text { jumlah seri } \\
\text { komputer yang } \\
\text { tidak } \\
\text { menggunakan } \\
\text { jaringan saraf } \\
\text { tiruan terhadap } \\
\text { pengguna dengan } \\
\text { username sesuai } \\
\text { dengan field } \\
\text { username }\end{array}$ \\
\hline kalah_nojst & int & 2 & $\begin{array}{c}\text { Menyimpan } \\
\text { jumlah kalah } \\
\text { komputer yang } \\
\text { tidak } \\
\text { menggunakan } \\
\text { jaringan saraf } \\
\text { tiruan terhadap } \\
\text { pengguna dengan } \\
\text { username sesuai } \\
\text { dengan field } \\
\text { username }\end{array}$ \\
\hline menang_jst & int & 2 & $\begin{array}{c}\text { Menyimpan } \\
\text { jumlah menang } \\
\text { komputer yang } \\
\text { menggunakan } \\
\text { jaringan saraf } \\
\text { tiruan untuk } \\
\text { melawan } \\
\text { pengguna dengan } \\
\text { username sesuai } \\
\text { dengan field } \\
\text { username }\end{array}$ \\
\hline seri_jst & int & 2 & $\begin{array}{c}\text { Menyimpan } \\
\text { jumlah seri } \\
\text { komputer yang } \\
\text { menggunakan } \\
\text { jaringan saraf } \\
\text { tiruan untuk }\end{array}$ \\
\hline
\end{tabular}

\begin{tabular}{|c|c|c|c|}
\hline & & & $\begin{array}{c}\text { melawan } \\
\text { pengguna dengan } \\
\text { username sesuai } \\
\text { dengan field } \\
\text { username }\end{array}$ \\
\hline kalah_jst & int & 2 & $\begin{array}{c}\text { Menyimpan } \\
\text { jumlah kalah } \\
\text { komputer yang } \\
\text { menggunakan } \\
\text { jaringan saraf } \\
\text { tiruan untuk } \\
\text { melawan } \\
\text { pengguna dengan } \\
\text { username sesuai } \\
\text { dengan field } \\
\text { username }\end{array}$ \\
\hline
\end{tabular}

Nama Tabel: tb_mse

Primary Key: username, pola, epoch

Keterangan: tabel 10 menunjukkan struktur tabel basis data yang digunakan untuk menyimpan nilai MSE dari setiap pelatihan

Tabel 10 Struktur Tabel MSE

\begin{tabular}{|c|c|c|c|}
\hline $\begin{array}{c}\text { Nama } \\
\text { Field }\end{array}$ & $\begin{array}{c}\text { Tipe } \\
\text { Data }\end{array}$ & Lebar & Deskripsi \\
\hline username & varchar & 30 & $\begin{array}{c}\text { Menyimpan } \\
\text { username dari } \\
\text { pengguna yang } \\
\text { dikenali oleh } \\
\text { jaringan saraf tiruan }\end{array}$ \\
\hline pola & int & 4 & $\begin{array}{c}\text { Menyimpan indeks } \\
\text { penunjuk pola }\end{array}$ \\
\hline epoch & int & 4 & $\begin{array}{c}\text { Menyimpan indeks } \\
\text { penunjuk jumlah } \\
\text { epoch yang telah } \\
\text { ditempuh }\end{array}$ \\
\hline mse & float & - & $\begin{array}{c}\text { Menyimpan nilai } \\
\text { MSE untuk pola dan } \\
\text { jumlah } \text { epoch yang } \\
\text { telah ditempuh yang } \\
\text { telah ditunjukkan } \\
\text { pada field pola dan } \\
\text { epoch }\end{array}$ \\
\hline
\end{tabular}

\section{IMPLEMENTASI}

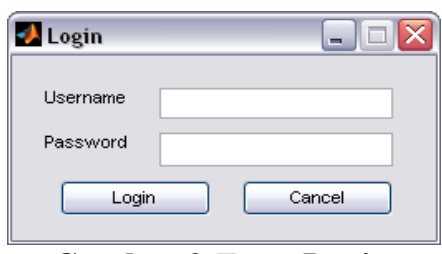

Gambar 2 Form Login

Gambar 2 menunjukkan tampilan dari form Login. Pengguna memasukkan username dan password mereka pada form ini. Jika tombol login di-klik dan password yang dimasukkan benar, maka form utama terbuka. Jika password yang dimasukkan salah atau username yang 
dimasukkan tidak ada, maka ditampilkan pesan kesalahan dan pengguna mengulang proses login.

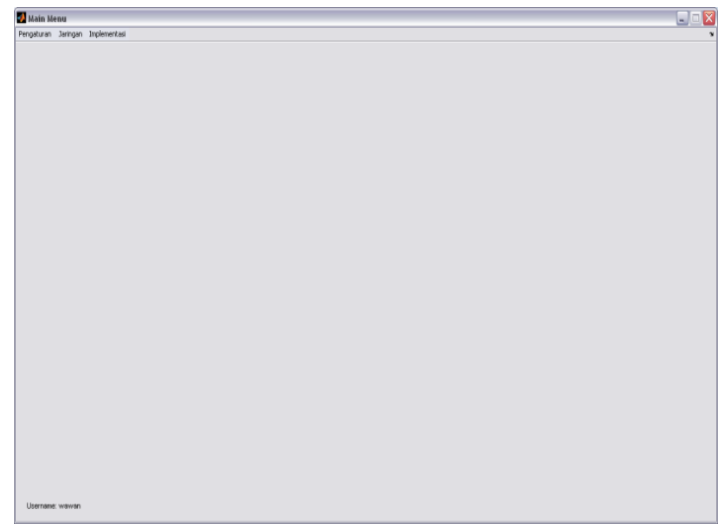

Gambar 3 Form Utama

Form Utama seperti yang terlihat pada gambar 3 terbuka jika pengguna biasa melakukan login. Pada form ini, pengguna bisa memilih menu yang tersedia untuk menggunakan aplikasi. Menu terbagi menjadi 3 sub menu, yaitu pengaturan, jaringan, dan implementasi. Pengaturan berisi menu ubah password. Jaringan berisi menu pelatihan jaringan saraf tiruan. Implementasi berisi menu implementasi dengan dan tanpa jaringan saraf tiruan.

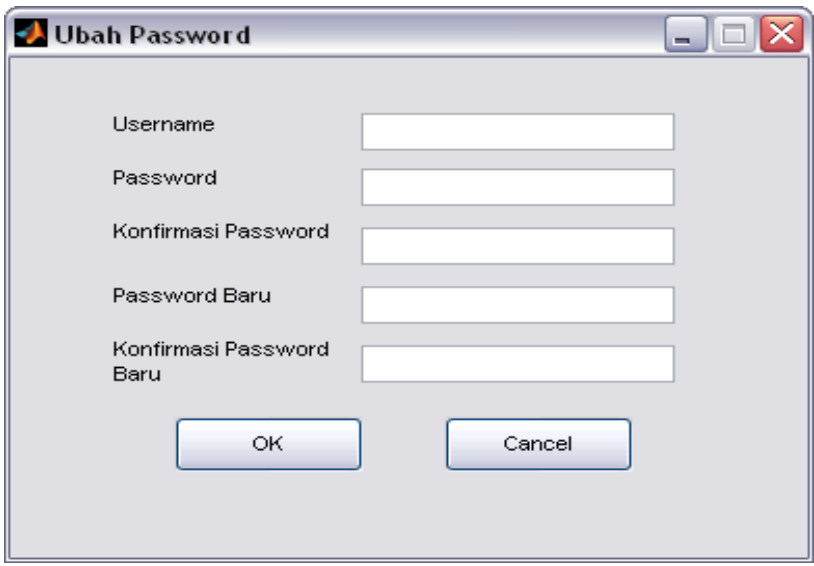

Gambar 4 Form Ubah Password

Pada form Ubah Password seperti yang terlihat pada gambar 4, pengguna dapat mengganti passwordnya untuk menjaga keamanan username mereka. Ketika tombol OK di-klik, maka aplikasi melakukan verifikasi konfirmasi password lama dan baru. Jika konfirmasi password lama atau konfirmasi password baru salah, maka ditampilkan pesan kesalahan.

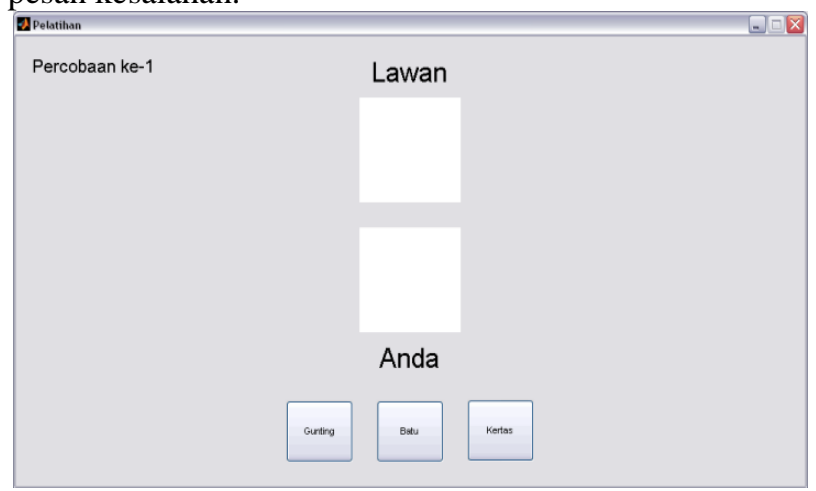

Gambar 5 Form Pelatihan Jaringan
Gambar 5 memperlihatkan tampilan dari form pelatihan jaringan. Pelatihan jaringan saraf tiruan dilakukan dengan melakukan permainan suten dalam 100 babak antara subjek penelitian dengan komputer. Pola yang terjadi selama permainan ini kemudian dikenali oleh jaringan saraf tiruan.

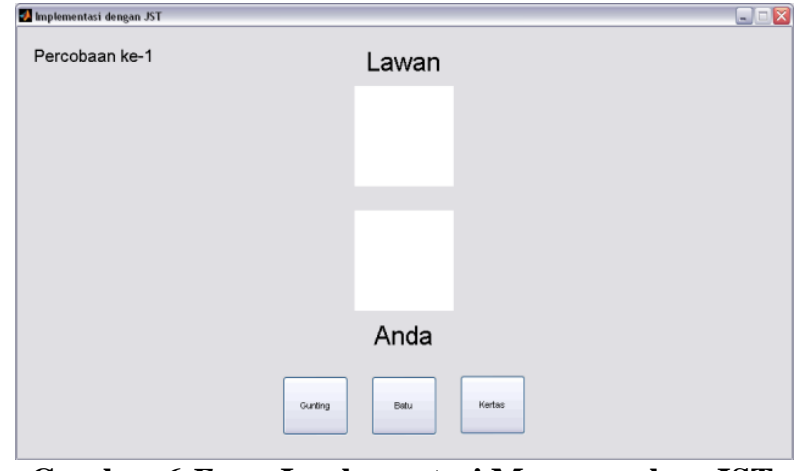

\section{Gambar 6 Form Implementasi Menggunakan JST}

Subjek penelitian melakukan permainan melawan komputer yang telah mengenali pola perilaku subjek penelitian menggunakan jaringan saraf tiruan menggunakan form implementasi dengan jst seperti yang terlihat pada gambar 6. Statistik kemenangan yang dihasilkan selama proses permainan dicatat sebagai bahan untuk menarik kesimpulan penelitian.

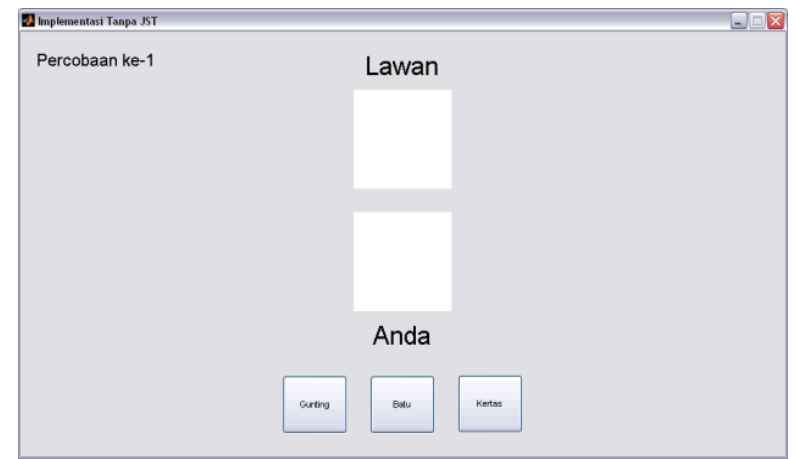

Gambar 7 Form Implementasi Tanpa JST

Pada form ini, subjek penelitian melakukan permainan melawan komputer yang tidak menggunakan jaringan saraf tiruan yang telah mengenali pola perilaku subjek penelitian menggunakan form implementasi tanpa jst seperti yang terlihat pada gambar 7. Statistik kemenangan yang dihasilkan selama proses permainan dicatat oleh peneliti sebagai bahan perbandingan terhadap data sebelumnya. 


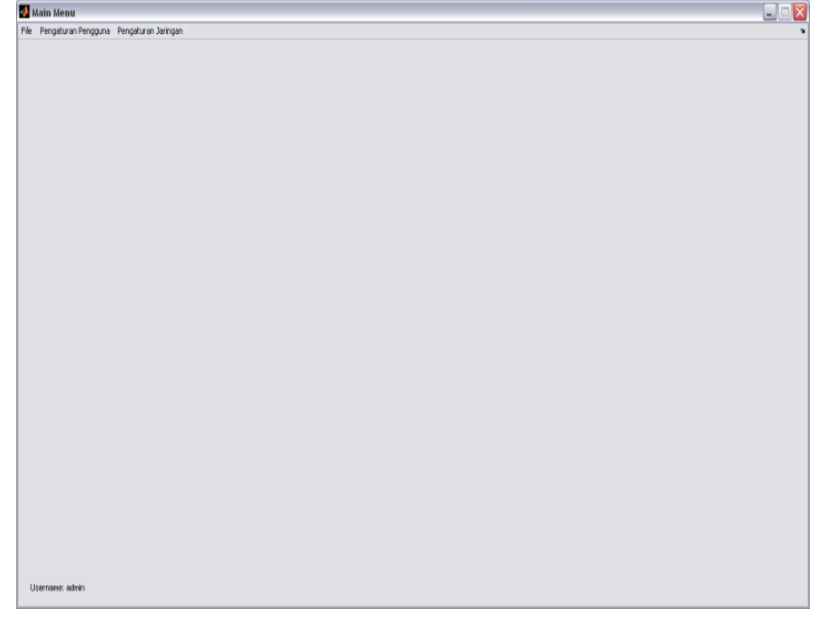

Gambar 8 Form Admin

Form admin dengan tampilan yang terlihat pada gambar 8 akan terbuka jika administrator sistem melakukan login. Pada form ini, administrator bisa memilih menu yang tersedia untuk menggunakan aplikasi. Menu terbagi menjadi 3 sub menu, yaitu file, pengaturan pengguna, dan pengaturan jaringan. File berisi menu untuk melihat statistik dari kemenangan komputer. Pengaturan pengguna berisi menu untuk menambah pengguna dan ubah password. Pengaturan jaringan berisi menu ubah parameter jaringan saraf tiruan.

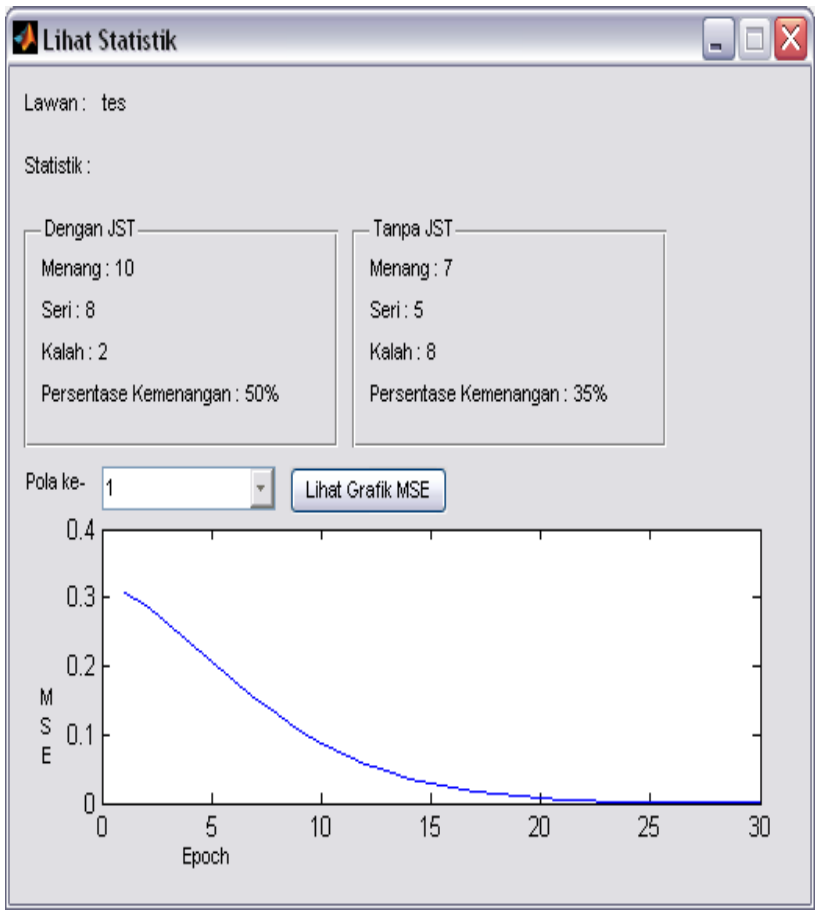

Gambar 9 Form Lihat Statistik

Pada form lihat statistik seperti yang terlihat pada gambar 9, administrator dapat melihat statistik dari kemenangan komputer terhadap salah satu pengguna.

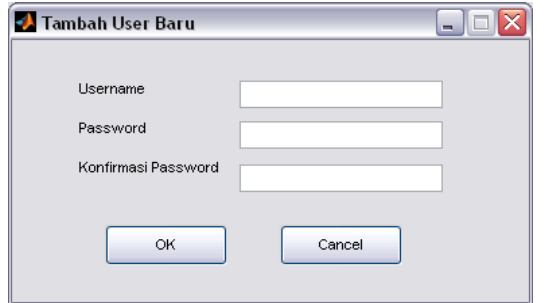

Gambar 10 Form Tambah Pengguna Baru

Dengan menggunakan form tambah pengguna baru yang tampilannya dapat dilihat pada gambar 54, peneliti dapat menambahkan pengguna baru yang nantinya akan berperan sebagai subjek penelitian baru.

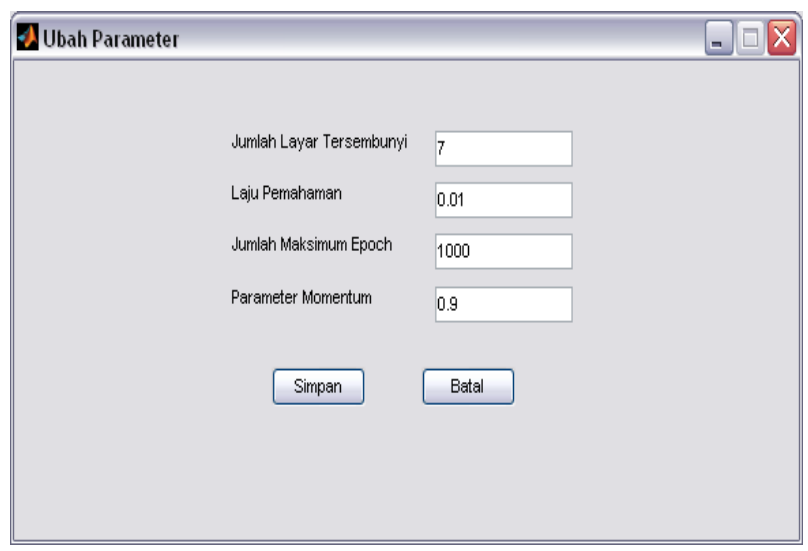

Gambar 10 Form Ubah Parameter Jaringan

Pada form ubah parameter jaringan saraf tiruan seperti yang terlihat pada gambar 55, peneliti dapat menyesuaikan parameter dari jaringan saraf tiruan yang akan digunakan untuk mengenali pola perilaku subjek penelitian dalam permainan suten. Penyesuaian dilakukan untuk mengoptimalkan kemampuan pengenalan dari jaringan saraf tiruan.

Kesimpulan yang didapatkan sebagai hasil penelitian ini ditarik berdasarkan data statistik kemenangan yang didapatkan dari hasil pengujian. Pertama, dihitung selisih antara persentase kemenangan komputer yang menggunakan jaringan saraf tiruan dengan yang tidak menggunakan jaringan saraf tiruan untuk setiap pengguna. Kemudian dihitung rata-rata dari seluruh selisih persentase tersebut. Nilai rata-rata tersebut menjadi tolak ukur efektivitas jaringan saraf tiruan dalam mengenali pola perilaku manusia dalam permainan suten pada penelitian ini.

Data statistik kemenangan tersebut ditampilkan pada tabel 11 . 
Tabel 11 Data Statistik Kemenangan

\begin{tabular}{|c|c|c|c|c|}
\hline Nama & Usia & $\begin{array}{c}\text { Jenis } \\
\text { Kelamin }\end{array}$ & \multicolumn{2}{|c|}{$\begin{array}{c}\text { Persentase } \\
\text { Kemenangan } \\
\text { Komputer }\end{array}$} \\
\cline { 4 - 5 } & & & $\begin{array}{c}\text { dengan } \\
\text { Jaringan } \\
\text { Saraf } \\
\text { Tiruan }\end{array}$ & $\begin{array}{c}\text { Tanpa } \\
\text { Jaringa } \\
\text { n Saraf } \\
\text { Tiruan }\end{array}$ \\
\hline $\begin{array}{c}\text { Hartopo } \\
\text { Cenggoro }\end{array}$ & 44 & Laki-laki & $35 \%$ & $35 \%$ \\
\hline $\begin{array}{c}\text { Lisawati } \\
\text { Suciatmaja }\end{array}$ & 43 & Perempuan & $55 \%$ & $20 \%$ \\
\hline $\begin{array}{c}\text { Tjeng Yogi } \\
\text { Cenggoro }\end{array}$ & 20 & Laki-laki & $30 \%$ & $10 \%$ \\
\hline
\end{tabular}

Perhitungan untuk mendapatkan nilai rata-rata sebagai tolak ukur efektivitas jaringan saraf tiruan dalam mengenali pola perilaku manusia dalam permainan suten pada penelitian ini dijelaskan pada persamaan 1:

$$
\bar{P}=\frac{\sum P_{j s t}-P}{n}
$$

Keterangan:

1. $\bar{P}=$ rata-rata selisih persentase antara persentase kemenangan komputer yang menggunakan jaringan saraf tiruan dan persentase kemenangan komputer yang tidak menggunakan jaringan saraf tiruan.

2. $P_{j s t}=$ persentase kemenangan komputer yang menggunakan jaringan saraf tiruan.

3. $P=$ persentase kemenangan komputer yang tidak menggunakan jaringan saraf tiruan.

4. $n=$ jumlah pengguna yang dikenali pola perilakunya dalam permainan suten oleh jaringan saraf tiruan dalam penelitian ini.

\section{KESIMPULAN}

Dengan adanya hasil penelitian yang dilaksanakan, maka peneliti menarik kesimpulan berdasarkan dari uraian yang telah dibahas, yaitu :

1. Jaringan saraf tiruan umpan maju dengan layar banyak menggunakan algoritma pelatihan propagasi balik dengan arsitektur empat neuron layar input, tujuh neuron layar tersembunyi, dan satu neuron layar output mampu mengenali pola perilaku manusia dalam permainan suten.

2. Dalam permainan suten antara komputer dan subjek penelitian, terdapat peningkatan persentase kemenangan komputer yang menggunakan jaringan saraf tiruan dibandingkan dengan komputer yang tidak menggunakan jaringan saraf tiruan. Rata-rata peningkatan persentase kemenangan adalah $18,33 \%$.

\section{SARAN}

Adapun saran-saran yang dapat dikemukakan yaitu sebagai berikut :

1. Sebaiknya dilakukan penelitian lebih lanjut dengan menggunakan jenis arsitektur jaringan saraf tiruan yang lain.

2. Sebaiknya dilakukan penelitian lebih lanjut dengan menggunakan variasi pelatihan propagasi balik yang lain.
3. Sebaiknya dilakukan penelitian lebih lanjut dengan menggunakan metode kecerdasan buatan lain yang mampu melakukan proses pembelajaran.

\section{DAFTAR PUSTAKA}

Fadlil, Abdul dan Hidayat, Ikhsan dan Sunardin, 2008, Sistem Pengenalan Wajah Secara Realtime Menggunakan Algoritma Jaringan Saraf Tiruan, http://journal.uii.ac.id/index.php/Snati/article/view/88 1, diakses 3 Oktober 2013.

Fisher, Len, 2008, Rock, Paper, Scissors Game Theory in Everyday Life, New York: Basic Books.

Fowler, Martin, 2005, UML Distilled 3th Ed. Panduan Singkat Bahasa Pemodelan Objek Standar, Yogyakarta: Andi Offset.

Hermawan, Arief, 2006, Jaringan Saraf Tiruan Teori dan Aplikasi, Yogyakarta: Andi Offset.

Ichwan, M., 2011, Pemrograman Basis Data Delphi 7 dan MySQL, Bandung: Informatika.

Kusumadewi, Sri, 2004, Membangun Jaringan Saraf Tiruan (Menggunakan MATLAB dan Excel Link), Yogyakarta: Graha Ilmu.

Laurens, Joyce Marcella, 2005, Arsitektur dan Perilaku Manusia, Jakarta: Grasindo.

Muis, Saludin, 2006, Teknik Jaringan Syaraf Tiruan, Yogyakarta: Graha Ilmu.

Mustafidah, Anifatul, 2009, Peramalan Harga Saham Menggunakan Metode Jaringan Saraf Tiruan Metode Probabilistik, Skripsi, tidak diterbitkan, Jurusan Teknik Informatika, Malang: Universitas Islam Negeri Maulana Malik Ibrahim.

Nugroho, Adi, 2004, Konsep Pengembangan Basis Data, Bandung: Penerbit Informatika.

Nugroho, Adi, 2010, Rekayasa Perangkat Lunak Berorientasi Objek dengan Metode USDP, Yogyakarta: Andi Offset.

Poerwadarminta, W.J.S., 2006, Kamus Umum Bahasa Indonesia Edisi Ketiga, Jakarta: Balai Pustaka.

Priyani, Dian Rizky Eko, 2009, Aplikasi Diagnosa Gangguan Lambung Melalui Citra Iris Mata dengan Jaringan Syaraf Tiruan Propagasi Balik, Skripsi, tidak diterbitkan, Jurusan Teknik Informatika, Jakarta: Universitas Pembangunan Nasional "Veteran".

Puspitaningrum, Diyah, 2006, Pengantar Jaringan Saraf Tiruan, Yogyakarta: Andi Offset.

Ramakrishnan, Raghu dan Gehrke, Johannes, 2004, Sistem Manajemen Database, Yogyakarta: Andi Offset.

S., Rosa A., dan Shalahuddin, M., 2011, Modul Pembelajaran Rekayasa Perangkat Lunak (Terstruktur dan Berorientasi Objek), Bandung: Modula.

Siang, Jok Jeng, 2005, Jaringan Saraf Tiruan dan Pemrogramannya Menggunakan MATLAB. Yogyakarta: Andi Offset.

Simarmata, Janner, 2010, Rekayasa Perangkat Lunak, Yogyakarta: Andi Offset. 